\title{
Perceptions of Johannesburg small business operators about their small business support systems
}

\author{
F.G. Netswera* \\ Technikon Southern Africa, Private Bag X6, Florida 1710 \\ Republic of South Africa \\ Gnetswer@tsa.ac.za
}

Received July 2001

\begin{abstract}
Central to the current South African economic debates are the issues of equity, black empowerment and the promotion of small business activities. The promotion of small business activities is felt relevant as they are assumed to be addressing most of the country's unemployment problem and those mentioned above while contributing largely to the GDP. Assumed problems facing this industry include the unavailability of support systems. This quantitative research explored through telephonic interviews, the perceptions of 60 Johannesburg small business operators of their small business support systems. The findings revealed access to information to be the perceived most important support system and business partnerships and subcontracting the least accessible.
\end{abstract}

*To whom all correspondence should be addressed.

\section{Introduction}

South African small business activities have received extensive coverage in recent years as they did during the emergence of the economies of newly industrialised economies (NIC), e.g. Taiwan, South Korea and Singapore in the 1960s (Gereffi \& Wyman, 1990; Agmon \& Drobnick, 1994). Big businesses on the other hand have for years enjoyed government; financiers and other stakeholder support than did small businesses throughout the world.

Most discussions on small business, which is high on the government agenda, revolve around the need to promote the small and medium enterprises (SMEs) activities as documented in the National Small Business Act of 1996 and through tax relief provisions (Katz, 1997). Several presidential addresses and government-led conferences have culminated beyond verbalised dedication but the establishment of government support institutions, the likes of Ntsika Enterprises Promotion Agency (NEPA) - a nonfinancial support agency, and Khula Enterprises Finance Limited - a wholesale financial mobilisation and credit guarantee institution. These are the two main statutory bodies established to support and assist SMEs.

Despite these efforts by government, proponents of small business development still argue that there is a lack of commitment to SME development by large corporations including the banking sector (Levy, 1996:11). Without the support of the banking sector in particular, which is supposed to extend credit to these businesses, it is argued that their survival will always remain their first priority focus.

\section{Problem statement}

Given the argument posed in this introduction, a basic question that one could possibly ask is: 'How do small business operators perceive their own support and what challenges faces them?' This paper intends to address some of the perceptions and challenges faced by the Johannesburg small businesses. It is argued that South African political past contributed to a greater extend to the state of small business development in the country. Current political scenario brought in new small business legislation and institutional configuration - state and non-state institutions at national and provincial levels, in order to create opportunities for their development (Ladzani, 2000:3).

\section{Objectives}

The objectives of this research were the following:

- To assess the general perceptions of Johannesburg small business operators of their small business support systems.

- To determine the importance attached to each small business support system and the accessibility of each.

\section{Concept clarity}

Classification and definition of South African small businesses for funding purposes by the Department of Trade and Industry is as follows:

'...A firm which employs less than 50, but more than 5 workers, utilising capital assets (excluding fixed property) 
valued at less than $R 2$ million with annual turnover of less than R6 million'.

(Katz, 1997)

A small business operator or entrepreneur is a person who perceives an opportunity to make a profit and has the ability to set about combining factors of production to realise profit. To be able to make use of such an opportunity, certain input factors, i.e. support systems, should be made available to the small business operator, e.g. training, funds, partnerships with other businesses (Macleod, 1995; Dorrian \& Lynas, 1987).

\section{Literature}

There is sufficient evidence that the economies of the South Asian countries like Taiwan, South Korea and Singapore prospered through small business protection and promotion activities such as import substitution and export promotion policies (Gereffi \& Wyman, 1990). International economics has since changed. The success of South African small business sector will be dependent on other forms of support and promotion. Policies such as those employed by the NICs, stated above are slowly disappearing since South Africa's re-admittance into the global economy.

SMEs activities account for Japan's bulk of business establishments; most of their employees are indispensable members of a free and robust market economy. Not only does SMEs provide vital support through employment for the regional economy but also account for the day-to-day life of most Japanese (MITI 1997:219). Other countries like the People's Republic of China and Taiwan have reported their SME sector to account for between 60 and $88 \%$ of the nation's total income (Annual Report 1982-1983).

In South Africa, SME development and support initiatives had been handled along the racial lines. This has been visible through the creation of two chambers, i.e., National African Federated Chamber of Commerce (NAFCOC), for Black businesses and the South African Camber of Business (SACOB) for White businesses. The history of the SME sector has proven its importance with $25 \%$ contribution to the gross domestic product (GDP) of the country, 38\% employment and responsible for $75 \%$ new jobs (Katz, 1997). There are currently more than 800000 small, medium and micro-enterprises in South Africa, absorbing about a quarter of the 15 million strong labour force; this is in addition to about 3,5 million people who are involved in some type of survivalist enterprise activities (Ladzani, 2000:2).

It is widely acknowledged that through its labour intensive production and utilisation of basic raw materials, the SME sector, unlike any other business sector, has the potential of reducing the capital cost of creating new jobs. This opportunity will fail if their current financial credit problems and lack of other support systems are not fully addressed. Where the Reconstruction and Development Programme (RDP) objectives are concerned, the National Manpower Commission (NMC) (NMC, 1993: 9) emphasises the potential of small enterprises to redistribute opportunities, realise black aspirations, play a socialising role, help in the provision of housing and promote enterpreneurship.

There seems to be little difference in failure rates of small businesses in both the developing and developed countries, with an estimation of $50 \%$ failure of all start-ups in their first years and 75 to $80 \%$ within the first three to five years in America (Anderson \& Dunkelburg 1990:5). 80\% of those started in South Africa-Durban were reported to have failed in 1995 (Macleod, 1995:15).

The government, Non Governmental Organisations (NGOs) and communities has realised the window of opportunity that small businesses have created. As a result, numerous SME development and promotion initiatives have been effected, the most recent, mainly by government include among others, the following:

(a) The Centre for Small Business Promotion, established through the Department of Trade and Industry (DTI) at National level is responsible for SMEs' policy-related matters and support programmes.

(b) Ntsika Enterprise Promotion Agency (NEPA). NEPA is responsible for non-financial services like marketing, training programmes, procurement advice, technology assistance and mentoring to firms. Most of these services are rendered to SMEs through services providers, e.g. Tender Advice Centres (TACs), Manufacturing Advisory Centres (MACs), Local Business Services Centres (LBSCs), NGOs and Community Based Organisations (CBOs).

(c) Khula Enterprise Finance Limited. Was established in 1996 under the Companies Act as a DTI initiative. Khula provides access to finance and extend credit guarantee for SMEs and was an initiative to deal with the inability of banks to support small enterprises. Khula also extend 'wholesale' finances to the NGOs that offer micro loans to starter entrepreneurs. Khula does not by itself lend money to small businesses but makes money available through the Credit Guarantee Scheme, The Retail Financial Intermediaries (RFIs) and the Micro Credit Outlets (MCOs). Through RFIs, small businesses can borrow amounts of R5 000 to 50 000. Credit guarantees of between R60 000 and 600000 can be made for small businesses through the banks

(http://www khula.org.za/division_credit html).

Although support providers are in place, certain businesses and prospective entrepreneurs, through either ignorance or lack of information could still remain unknowledgeable about the availability and accessibility of these support systems (Macleod, 1995:16). These 'complaints' are often cited in popular magazines and newspapers and it is the purpose of this scientific inquiry to investigate all possible claims and perceptions. The followed methodological processes in attaining the set objectives are documented below. 


\section{Research procedure}

In order to meet the set objectives for this research, practicable research methodologies of a quantitative survey, were followed (Mouton, 1996; Babbie, 1995). A registry referred to as a 'journal' of all tax-paying and registered small businesses in Johannesburg was obtained from the Johannesburg Chamber of Commerce (JCC). It is from this journal where a total of 60 small businesses were sampled. The sampling method utilised was systematic, assumed to be giving all prospective respondents an equal chance of being selected and therefore participate in the survey, i.e. probabilistic (Mouton, 1996).

\section{Instrumentation}

A questionnaire was developed for data collection purposes from mainly the relevant SMEs literature including the National Small Business Act of 1996 and other small business policy related documents. The developed questionnaire collected three types of data: biographical, small business activities and perceptual data, which are Likert-scale type and Thurstone's comparative data. The Likert questions, i.e. 31 items (Goode \& Hatt, 1981: 272), assessed perceptions. The Thurstone's Law of Comparative Judgement ranked order in importance the four given support system to small business. As identified by Dorrian and Lynas (1987) the most important support systems are finance, Training, Access to information and Business partnerships \& subcontracting, also see the White Paper on National Strategy for the Development and Promotion of Small Business in South Africa (1995).

To ensure validity and reliability of the questionnaire, a pilot was conducted. Two small business operators and two small business management senior lecturing staff were asked to respectively respond and review the questionnaire making suggestions while gauging easiness and clarity of posed questions.

\section{Fieldwork}

The chosen data collection method was telephonic interviews, viewed to be more effective in terms of response rates, in area and time coverage. All the sampled small businesses were contacted telephonically; briefed about the research project and consent to interview the business manager was asked. Anonymity of the interviewed businesses and names of interviewees was assured including the confidentiality to reveal or link respondents to any 'sensitive' information that they gave over and above the interview questions (Goode \& Hatt, 1981; Babbie, 1995).

Notably for some business managers there was enthusiasm to get through with the interviews immediately, probing the importance of this research activity and offering more information and documentation, and also looking forward to receiving a report of the results. From the rest, there was resentment of the research activity and resistance to participate. Through probing, the researcher established that resistance to participate is based on respondents' past experiences where similar research did not lead to improvement in their conditions, and participation was thus seen as a waste of time. The data collection process took an entire week of June - 2000.

\section{Results and discussion}

Results of this study are presented in the sequence in which the data was collected through the questionnaire, i.e. in three sections - biographical information of the respondents (business operators), their perception of small business support systems (availability and accessibility) and lastly the importance of each.

\section{Biographical characteristics}

The interviewed respondents comprised $83 \%$ males and $17 \%$ females in the age groups 30 years and younger $(5 \%)$, 31 to $40(32 \%)$, and 40 years and older $(63 \%)$. Racial composition is $92 \%$ whites, 5\% Asians and 3\% blacks $(n=60)$, confirming the assumption that blacks who are in small business activities are mainly involved in unregistered and informal activities (Macleod, 1995:16). It is here were current debates on black empowerment as raised by the Employment Equity Act of 1998 become relevant to encourage black entrepreneurs to enter the formal business domain. The sampled small businesses could be categorised in three main industries as also confirmed by the business directory from which they were sampled and by the respondents themselves.

Table 1: Industry and type of small businesses interviewed $(\mathrm{N}=60)$

\begin{tabular}{llllll}
\hline \multicolumn{2}{c}{ Manufacturing } & \multicolumn{2}{c}{ Sales } & \multicolumn{2}{c}{ Services } \\
\hline & $\boldsymbol{N}(\boldsymbol{\%})$ & & $\boldsymbol{N ( \% )}$ & $\boldsymbol{N}(\boldsymbol{\%})$ \\
\hline Furniture & $11(64.7)$ & Books \& stationary & $4(16.7)$ & Security & $6(31.6)$ \\
Glue produce & $1(5.9)$ & Building materials & $3(12.5)$ & TV \& video repairs & $2(10.5)$ \\
Stones \& granite & $5(29.4)$ & Machinery tools & $4(16.7)$ & Catering & $2(10.5)$ \\
& & Electronic & $7(29.1)$ & Communication systems & $1(5.3)$ \\
& & Computers & $6(25)$ & Plumbing & $8(42.1)$ \\
\hline Total = 60 & $\mathbf{1 7 ( 2 8 . 4 )}$ & & $\mathbf{2 4 ( 4 0 )}$ & & $\mathbf{1 9 ( 3 1 . 6 )}$ \\
\hline
\end{tabular}


The experiences, challenges and support needs of small business in each of the three industries are somewhat different as will be fully illustrated in figure 2 .

Business age of each of the categories varies from $36(60 \%)$ started before 1983; 11 (18\%) between 1983 and 1988; 10 (17\%) after 1994 and 3 (5\%) after 1994. Macleod (1995) believes that the basic understanding of economic activities and business principles is central to securing, among other things, finance and business contracts. The basic understanding of the market and economic activities can either be embedded in one's experiences in the industry overtime or academic standing. It is for this reason that respondents' academic qualifications were required. Respondents' general academic qualifications indicate that they have a good understanding and have developed the necessary aptitude to reach the goals of a small business. Their qualifications vary between matric $(25 \%)$, post-school diploma (23\%), degrees $(23 \%)$ and postgraduate degrees $(14 \%)$ and other $(15 \%)$. The respondents' number of years of involvement in these business activities is presented in the table below.

Table 2: Number of years by type of involvement in business activities

\begin{tabular}{lllll}
\hline Number of years involved & \multicolumn{4}{c}{ Involvement capacity } \\
\cline { 2 - 5 } & $\begin{array}{l}\text { Employee } \\
\text { N(\%) }\end{array}$ & $\begin{array}{l}\text { Owner } \\
\mathbf{N}(\%)\end{array}$ & $\begin{array}{l}\text { Manager } \\
\text { N(\%) }\end{array}$ & $\begin{array}{l}\text { Total } \\
\text { N(\%) }\end{array}$ \\
\hline Less than 10 years & $6(10.3)$ & $5(8.6)$ & $10(17.2)$ & $21(36.2)$ \\
\hline Between 10 \& 19 years & $2(3.4)$ & $5(8.6)$ & $1(1.7)$ & $8(13.8)$ \\
\hline Between 20 \& 29 years & $15(25.9)$ & $2(3.4)$ & $3(5.1)$ & $20(34.5)$ \\
\hline Between 30 \& 39 years & $1(1.7)$ & $3(5.2)$ & $1(2.4)$ & $6(10.3)$ \\
\hline 40 years & $3(5.2)$ & - & - & $3(5.2)$ \\
\hline Total & $\mathbf{2 7 ( 4 6 . 6 )}$ & $\mathbf{1 5 ( 2 5 . 9 )}$ & $\mathbf{1 6 ( 2 7 . 6 )}$ & $\mathbf{5 8 ( 1 0 0 )}$ \\
\hline
\end{tabular}

The original idea was to interview business managers or owners, however some of these referred the interviews to either their directors or managers and even employees who had a thorough understanding of the business and the business owner. As a result, $46.6 \%$ of the interviews were held with employees most of whom had been in business for 20 to 29 years $(25.9 \%), 25.9 \%$ owners and $27.6 \%$ managers/directors. $67 \%$ of all businesses sold their products to local markets and $33 \%$ to both local and international markets. $65 \%$ of all respondents had total business assets of less than R1 million, and $35 \%$ of the respondents had assets between R1 million and R6 million, while annual income ranged between 0 to $\mathrm{R} 1$ million for $54 \%$, and between R1 million and R6 million for $46 \%$.

\section{Perception on small business support systems}

An analysis of the Likert-scale questions provides a general perception on small business support systems. The analysis revealed that training for skill development and improvement is the most accessible support system (cf. figure 2). Hands-on, managerial and staff development training are indicated to be the most available form of training for small businesses. Although hands-on training is perceived by $74 \%$ to be the most effective form of training and expected to be provided through subcontracts by big businesses, it is however the list available.

Finance, which is the type of support given most attention and always assumed to be a first priority small business support system by authors like Levy (1996) was revealed as second accessible after training. 23\% have experienced financial problems in the past and received assistance from banks, and $80 \%$ did not receive any assistance even on request. Government-sponsored financial institutions such as the Development Bank (DBSA) and Khula Enterprises are reported to be the most prepared in assisting with financial problems either directly or indirectly as also claimed by Macleod (1995).

Business partnering activities such as subcontracting and franchises are said to be positive initiatives necessary for building small business capacities in terms of both training, skills development and securing contracts. $76 \%$ are in favour and willing to form partnerships with big businesses although $70 \%$ of those who have approached big businesses report on their unwillingness to co-operate. $64 \%$ believed that franchises, another form of partnering is a good skillsimparting activity, although it takes partial independence away form the business owner (Hubbard \& Hailes, 1988).

Perceived accessibility of certain support systems could easily be construed to mean- easily available and provided on request. Although the location of most of these support systems is known and have on numerous occasions been requested, certain requirements obstruct attainment and usage. Figure 2 indicates the services that interviewed businesses did request and receive, including the type of institutions that made such support available. 


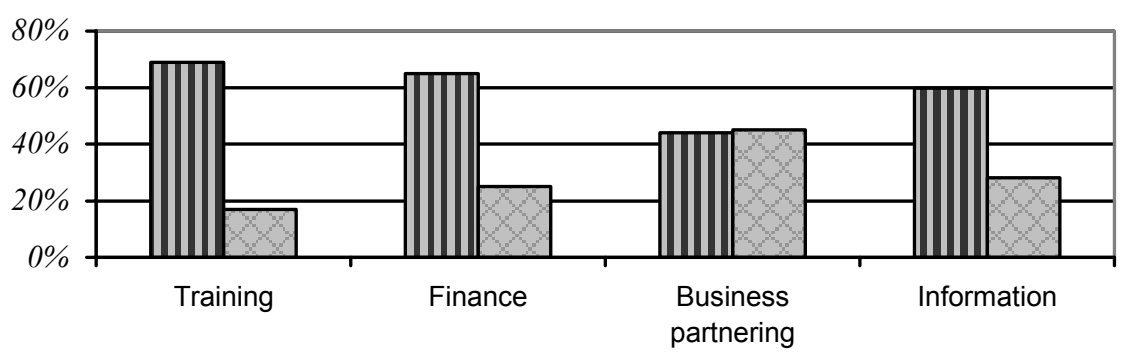

$\square$ Accessible $\square$ Inaccessible

Figure 1: Accessibility of small business support systems

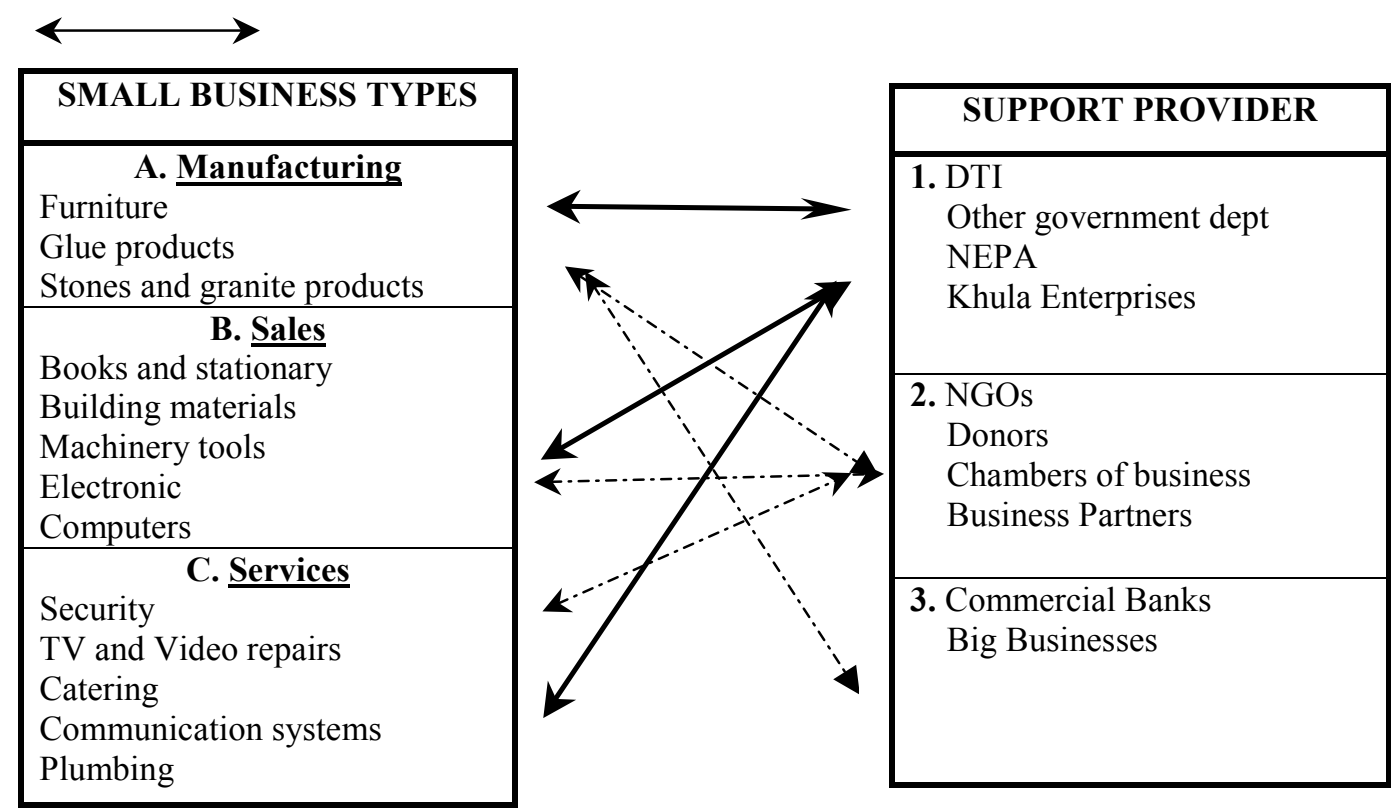

- Where sought, $50-100 \%$ received

<-...-> • Where sought, $<50 \%$ received

Figure 2: Accessibility of small business support systems

As indicated in figure 2 , it is evident that all small businesses from the three sectors represented in the sample i.e., manufacturing, sales and services are optimistic in receiving support from the government and government linked organisations. The systems indicated to be frequently requested and received are those that are made available through NEPA, which are mainly advice and information on among others training and credit guarantees from Khula. As already discussed, less than $20 \%$ of those that request financial support did receive it through banks than through RFIs and MCOs.

Access to information, which is reported third accessible in figure 1, includes both receipt of information by the business and also, availing the small business information to public through advertising media such as newspapers, television and radio. $87 \%$ respondents indicate to be making use of advertisements as a form of attracting customers, however $80 \%$ consider the mentioned advertising media to be expensive. Although there is relatively good access to information, advertising cost implications makes availing small business information less accessible.

The relationship between all the small business types and support provider no 2 indicates sought and often received support, however in less than $50 \%$ cases. Main support here is also information on registration, promotion and marketing services by and through the business chambers, with little funding requests from donors. The much-needed support by the manufacturing businesses (from support 3 ) is in the form of funds and subcontracting and partnership alliances. The unwillingness of big businesses to participate in these ventures, which have skills development and capacity building opportunities for small business is already stated. 
Availability, accessibility and receipt of some business support systems do not necessarily indicate their importance. There are those support systems without which some businesses could cease to function or even close.

\section{Importance of various support systems}

In order to determine the importance of each given support system, Thurstone's Law of Comparative Judgement was used (Goode \& Hatt, 1981:272). Presenting the four support systems in pairwise comparison gives rise to discriminatory choice about the perceived importance of each in a pair. Each pairwise comparison is tested repeatedly against one individual respondent and among different individuals. The number of pairwise comparisons is determined by formula $n$ $(n-1) / 2$, where $n$ is the number of support systems. In this regard six pairwise comparisons were presented to respondents to rank order importance.

Frequency averages for each support system for the given pairwise comparisons of the four support systems reveal access to information (59\%) as the perceived most important support system. These findings supports those reflected in figure 2 where most of the required support had been information through NEPA and other government and government linked institutions. This means therefore that without access to information and the ability to avail own information and advertisements to the public, most of these small businesses believe they would not be able to function. The importance of information services is also linked to training and skill development (58\%), which is perceived to be the second most important form of support required.

Access to finance (51\%) is regarded the third most important form of support required by small businesses and business partnerships in the form of subcontracts and franchises, the last important form of support required. Although business partnerships is regarded the least important form of support, it is revealed as the most important form of support requirement by the manufacturing type of businesses.

\section{Recommendations and conclusions}

All the necessary policies on small business development and promotion are in place. The South African government has put in place the basics, i.e., the right policies and support organisations like Ntsika and Khula. How well these policies and mentioned institutions are functioning is a separate matter not discussed in this research.

Enthusiasm to participate in this study and to let government and other support agencies know precisely what small business operators think about their own situation was evident throughout interviews. Disillusionment was however also found to exist in some business operators who have lost faith in research and the fact that someone out there is willing to assist them.

The following issues are recommended in order to promote the development and success of small businesses in Johannesburg; also important for policy formulation and amendments:
- Although finance has always been perceived to be the most important small business support system, this research revealed that access to information is the most important support system. This perception should be further validated to prioritise the support types to be made available.

- Collaboration. Big businesses should be encouraged and where necessary rewarded for joint projects, subcontracts with small businesses.

- Training. Although basic training is necessary, the extended monitoring and support in the form of aftercare should be more visible.

For further research, it is recommended that the sample size used here be expanded to give a full coverage that would enable generalisations to the Johannesburg small businesses. Continuous assessment, which will reveal the successes of current support systems and challenges that small business face, should be given attention.

This study gets published at a time when NAFCOC and SACOB are to be merged. It is hoped that this will overcome the racial factors overlooked in the past, also visible in representation in this study's sample.

\section{Limitations of the study}

Although triangulation of information sources could have added the much needed value, the study did not secure inputs from the business chambers were these small businesses are registered. Organisations like Khula Enterprises and NEPA if interviewed would also have provided valuable information. Such type of information could have validated the findings and claims made by small business operators.

Due to absence of financing of this research, the researcher had to use his personal funds. This has added unnecessary limitations such as the use of a small sample size.

\section{References}

Annual Report. 1982-1983. Financial and Management Services to Small/Medium Business in Taiwan, the Republic of China. Preface (1): p.3.

Agmon, T. \& Drobnick, R. 1994. Small firm in global competition. New York: Oxford.

Babbie, E. 1995. The practice of social research. 7th Edition. Belmont-California: Wadsworth Publishing Co.

Dorrian, A. P. \& Lynas, M.G. 1987. Managing the smaller firm: "The South African context". Johannesburg: Southern Books.

Goode, J. \& Hatt, K. 1981. Methods in social research. Singapore: McGraw-Hill. International Student Edition.

Gereffi, G. \& Wyman, D. 1990. Manufacturing miracles: paths of industrialization in Latin America and East Asia. New Jersey: Princeton University Press. 
Hubbard, R. T. \& Hailes, W. D. (Jr.) 1988. Small business management. $4^{\text {th }}$ Edition. New York: Delmar Publishers.

Katz, M. M. 1997. Fifth interim report of the commission of inquiry into certain aspects of the tax structure of $S A$. Pretoria: Government Printer.

Khula Enterprise Finance Limited. 2001. Types of Credit guarantees. Available on the Internet at: http://www.khula.org.za/divisions credit html

Ladzani, W. 2000. Small business development in South Africa under the majority rule. Unpublished: Technikon Southern Africa.

Levy, B. 1996. South Africa: The business environment for industrial small and medium enterprise. Washington DC: The World Bank's South African Department.

Macleod, G. 1995. Starting your own business in South Africa. $8^{\text {th }}$ Edition. Cape Town: Oxford University Press.

Ministry of International Trade and Industry (MITI). 1997. White paper on small and medium enterprises in Japan.

Tokyo: Small and Medium Enterprise Agency.

Mouton, J. 1996. Understanding social research. Pretoria: Van Schaik.

National Manpower Commission (NMC). 1993. Annual Report - National Manpower Commission. Pretoria: Government Printer.

South Africa. 1998. Employment Equity Act 55 of 1998. Pretoria: Government Printer.

South Africa. 1996. National Small Business Act 102 of 1996. Pretoria: Government Printer.

South Africa. 1995. White paper on national strategy for the development and promotion of small businesses in South Africa. Pretoria: Government Printer. 